\title{
Fate of urea fertilizers in sandy aquifers: laboratory and field case study from Kalpitiya, Sri Lanka
}

\author{
Pathmakumara Jayasingha ${ }^{* 1,2}$, A. Pitawala ${ }^{3}$ and H.A. Dharmagunawardhana ${ }^{3}$ \\ ${ }^{1}$ Postgraduate Institute of Science, University of Peradeniya, Peradeniya. \\ ${ }^{2}$ Research Laboratory, Central Cultural Fund, Independence Avenue, Colombo 07. \\ ${ }^{3}$ Department of Geology, Faculty of Science, University of Peradeniya, Peradeniya.
}

Revised: 31 December 2012; Accepted: 14 February 2013

\begin{abstract}
High nitrate $\left(\mathrm{NO}_{3}^{-}\right)$levels in groundwater are attributed to fertilizer leaching from sandy soil. A simulation laboratory study was performed to investigate the fate of leached urea in an agricultural field in Kalpitiya and the enhancement of fertilizer retention in sandy soil. A field experiment was conducted to investigate the effectiveness of using nutrient rich groundwater to reduce the nitrate levels in the Kalpitiya aquifer. Nitrate retention experiment revealed that increasing clay up to $15 \%$ increased the retention by $>50 \%$ with an efficiency of $3.7 \%$ and the retention is conversely correlated with the quantity of clay. A soil column experiment showed that nitrate concentration of leachate increases rapidly for an initial period of 250 hours and then started to decrease gradually. Initial nitrification followed by denitrification reactions may be the causative factors for this behaviour. The study further revealed that clay and organic manure are potential sinks of nitrate while the latter is also a source of nitrate. Gradual building up of nitrate in the groundwater of the aquifer system appears to be due to available favourable conditions for continuous nitrification while cycling through the aquifer due to intensive irrigation. This field case study reveals that a polluted aquifer can probably be recovered by reusing the nitrate contaminated groundwater as a source of fertilizer for the crops cultivated on the land above the aquifer allowing longer contact time for plant uptake. The process can gradually purify the groundwater while allowing farmers to use less nitrate fertilizers.
\end{abstract}

Keywards: Groundwater pollution, Kalpitiya, nitrate, urea fertilizer.

\section{INTRODUCTION}

Groundwater contamination due to excess urea applications

Urea, as a nitrogen $(\mathrm{N})$ fertilizer, is commonly used in the agricultural sector (Ghosh \& Bhat, 1998; Guo et al., 2004). Hydrolysis, volatilization, nitrification and denitrification are the important processes that decide the fate of applied urea (Rao \& Puttanna, 1987; Liang et al., 2004; Khalil et al., 2009). Once urea is applied to soil, it hydrolyses to form $\mathrm{NH}_{4}^{+}$. Nitrification converts $\mathrm{NH}_{4}^{+}$into $\mathrm{NO}_{2}{ }^{-}$and the nitrite is transformed into $\mathrm{NO}_{3}^{-}$(Schlesinger, 1997; Liyang et al., 2007; Khalil et al., 2009). Denitrification removes $\mathrm{NO}_{3}^{-}$from the soil system as $\mathrm{N}_{2}$ gas (Choudhury $\&$ Kennedy, 2005). However, N-transformation processes are complicated and dependent on the characteristics of soils (Nakasone et al., 2004; Yoshinaga et al., 2004; Evans et al., 2006).

The retention of $\mathrm{N}$ fertilizers depends on clay and organic matter content of the soil, the irrigation pattern and the amount and type of fertilizer applied to the soil (Simpson, 2006; Ahmadil et al., 2010; Fan et al., 2010; Latifah et al., 2011). Sandy soil, which is in poor organic matter, clay and silt hardly retain the applied urea (Hallberg, 1989). Hence excess application and poor soil management techniques cause leaching of applied urea fertilizers (Gusman \& Marino, 1999; Bigelow et al., 2001; Jalali, 2005). High nitrate contents are recorded in groundwater of such agricultural fields (Strebel et al., 1989; Zebarth et al., 1998).

Agricultural activities and nitrate pollution of groundwater in Kalpitiya area

Although Kalpitiya is one of the highly productive agricultural areas of the country, the sandy soil of the area is low in nutrient and water retention capacities. Due to dry climatic conditions the intense irrigation is 
common. Highly permeable sandy soil coupled with intense watering causes a significant loss of applied urea through leaching that results in contamination of the shallow aquifer system. Farmers in the area apply excessive amounts of nitrogen fertilizer expecting better yields from the infertile sandy soil. Leaching losses during rainy seasons are also compensated by applying large amounts of fertilizer. A gradual accumulation of nutrients in groundwater has taken place and the nitrate pollution of groundwater in the area has risen to alarming levels at present. Groundwater contamination in terms of nitrate pollution in the area has been studied for several decades (Lawrence \& Kuruppuarachchi, 1986; Mubarak et al., 1992; Kuruppuarachchi \& Fernando, 1999; Liyanage et al., 2000). Recent investigations revealed that nitrate levels in groundwater at some places in Kalpitiya agricultural fields is as high as $212 \mathrm{mg} / \mathrm{L}$ during dry periods and more than $50 \%$ of the studied wells have nitrate levels exceeding the WHO allowable limits (Jayasingha et al., 2011). It was also found that the nitrate accumulation rate is $2.3 \mathrm{mg} / \mathrm{L}$ per year for the last 10 year period. Further, the nitrate pollution in the area is considerably high compared to the other agricultural areas of the country (Young et al., 2010).

Although many researchers have focused on the water quality in the Kalpitiya area, the process involved in the increasing of nitrate levels has not yet been investigated. The continuous accumulation of nitrates in the aquifer may have resulted from the conversion processes such as rapid oxidation of urea into nitrate in surface sandy soil, in soil profile during leaching and/or in aerobic zone of the aquifer water. Understanding the nitrogen cycle in the area is a timely need in order to find remedial measures to recover the contaminated aquifer and to prevent further nitrate contamination.

The present study was aimed to (i) understand the behaviour of urea in the Kalpitiya sandy soil and its leachates in the aquifer, (ii) suggest a possible method to enhance fertilizer retention in the sandy soil and (iii) identify an effective method to remove the already accumulated nitrate in the Kalpitiya groundwater. To achieve these objectives a laboratory simulation of field conditions and a field experiment were carried out.

\section{METHODS AND MATERIALS}

\section{Material characterization}

The sandy soil and the clay soil for the laboratory experiments were collected from the study area and its surroundings. The textural characteristics of soil were determined by particle size analysis according to the
ASTM standards (ASTM D422-63, 2007). Commercially available organic manure (OM) applied as organic fertilizer was also used for the study. The $\mathrm{pH}$ of the soil and OM was measured by adding distilled water into soil (1:1 ratio) and duplicated with each soil sample (USDA No.18, 1951). The amount of organic matter in materials used was calculated by ignition loss method (Dean, 1974).

\section{Determination of the amount of nitrate absorption with respect to clay content}

$100 \mathrm{~mL}$ of potassium nitrate $\left(\mathrm{KNO}_{3}\right)$ solution (25 $\mathrm{mg} / \mathrm{L}$ ) was added to a mixture of $99 \mathrm{~g}$ of sand and $1 \mathrm{~g}$ of clay with a total weight of $100 \mathrm{~g}$. The mixture was continuously stirred by a magnetic stirrer for $15 \mathrm{mins}$. The solution was kept 30 min for settling and the supernatant was analysed for nitrate- $\mathrm{N}$ by the cadmium reduction method (high range, $0-30 \mathrm{mg} / \mathrm{L}$ ) using a HATCH DR/2400 spectrophotometer. Similar experiments were conducted with mixtures comprising different proportions of clay and sand (Table 1). The experiments were duplicated to minimize analytical errors and the average values were used for data interpretations.

\section{Soil column treatment}

Four soil columns were prepared in PVC pipes (height $-100 \mathrm{~cm}$, diameter $-10 \mathrm{~cm}$ ) by filling them with (i) sandy soil with $10 \%$ clay; (ii) sandy soil with $10 \%$ OM; (iii) sandy soil with $5 \%$ clay and $5 \%$ OM; (iv) only sandy soil. OM was thoroughly washed with distilled water and air dried prior to mixing. As a control, a separate soil column was prepared by using sand, which was heated for $12 \mathrm{hrs}$ at $350{ }^{\circ} \mathrm{C}$. Each column was filled completely with the mixtures and lightly packed, simulating the field conditions. Nitrate contents of all untreated soil mixtures were determined prior to the experiment. The nitrogen fertilizer (urea) solution prepared by dissolving $1 \mathrm{~g}$ of commercially available urea in $1 \mathrm{~L}$ of distilled water was added to each column and the leachates were collected from the bottom. The differences of nitrate-N content of the leachates with time was studied. The duration of the study was 60 days.

\section{Use of nitrate rich groundwater for irrigation}

Two vegetable plots (bed A and bed B) were prepared in the field to cultivate red onion (Allium cepa), which is a commercially cultivated short term (3.5 months) crop in the area. The beds (sand) of $2.5^{\prime} \times 6^{\prime}$ size with side walls were prepared after lining the beds with commercially available polythene sheets at a depth of 8 inches below the surface. The onion seeds were planted in both lined beds and in normal beds (unlined) of an agricultural 
field. Similar conditions were maintained for both types of beds. Fertilizer was not added to bed A and other fertilizers except urea were added to bed B to allow the nitrate requirement of plants to be met only by irrigated groundwater obtained from a tube well installed in the same land, which had a concentration of about $100 \mathrm{mg} / \mathrm{L}$ of nitrate. During the experiment, growth rate of plants was studied. Harvested yields of each controlled plots were measured and compared.

\section{RESULTS}

\section{Characteristics of used materials}

The textural study revealed that the collected sandy soil was fine to medium grained and composed of $99 \%$ sand. Soils were characterized by $95 \%$ of quartz with minor amounts of ilmenite and magnetite. Organic matter content of sandy soil was less than $1 \%$ and the $\mathrm{pH}$ varied from 6.8 to 7.9 with a mean of 7.3. Clay soil was composed of $97 \%$ fine fraction ( silt + clay) with a mean $\mathrm{pH}$ of 7.5 and was free from organic matter. Commercially available organic fertilizer contained more than $96 \%$ of organic content and the $\mathrm{pH}$ was 3.6.

Table 1: Nitrate-N content of the supernatant solution with the increase of clay fraction in the mixture

\begin{tabular}{cccc}
\hline $\begin{array}{c}\text { Mixture } \\
\text { no. }\end{array}$ & $\begin{array}{c}\text { Sand content } \\
(\mathrm{g})\end{array}$ & $\begin{array}{c}\text { Clay content } \\
(\mathrm{g})\end{array}$ & $\begin{array}{c}\text { Mean nitrate content } \\
\text { in the solution } \\
(\mathrm{mg} / \mathrm{L})\end{array}$ \\
\hline M1 & 99 & 1 & 23.8 \\
M2 & 98 & 2 & 22.7 \\
M3 & 97 & 3 & 22.3 \\
M4 & 96 & 4 & 21.2 \\
M5 & 95 & 5 & 20.8 \\
M6 & 94 & 6 & 19.5 \\
M7 & 93 & 7 & 18.9 \\
M8 & 92 & 8 & 17.4 \\
M9 & 91 & 9 & 16.8 \\
M10 & 90 & 10 & 16.2 \\
M11 & 89 & 11 & 15.4 \\
M12 & 88 & 12 & 14.8 \\
M13 & 87 & 13 & 13.7 \\
M14 & 86 & 14 & 13.4 \\
M15 & 85 & 15 & 12.1 \\
\hline
\end{tabular}

Variation of nitrate concentrations in supernatant solutions after different durations

The retention of nitrate by the clay fraction was noted since nitrate contents of the supernatant solution decreased with the increase in clay content of the soil mixture (Table 1). The results show that more than $50 \%$ of the added nitrate can be retained when $15 \%$ of clay is added into the sandy soil. However, the mean retention efficiency of $1 \mathrm{~g}$ of added clay in the experiment was $3.7 \%(n=30)$.

\section{Variation of leached nitrate concentrations from different soil mixtures}

The variation of leached nitrate concentrations from the treated columns showed two different patterns (Figure 1); (i) rapid increase during the initial stage and (ii) slow and steady decline in the latter part of the study. However, the rates of variations differed with different soil mixtures.

The sand (only) column showed the lowest concentration of leached nitrate throughout both phases and the rate during the increasing phase at 24 hours was $0.024 \mathrm{mg} / \mathrm{L} / \mathrm{h}$. It showed an increasing trend up to its maximum at 288 hours and the rate was $0.069 \mathrm{mg} / \mathrm{L} / \mathrm{h}$. The rate of the declining phase $(0.020 \mathrm{mg} / \mathrm{L} / \mathrm{h})$ was gradual and became constant in the latter part. The highest leached nitrate content $(37.49 \mathrm{mg} / \mathrm{L})$ was recorded from sand+OM mixture. Leached nitrate content in sand+OM increased rapidly within the first 24 hours with a rate of $0.501 \mathrm{mg} / \mathrm{L} / \mathrm{h}$ and it was the most significant rising phase. At the maximum the nitrate content was $0.118 \mathrm{mg} / \mathrm{L} / \mathrm{h}$. It declined at a rate of $0.023 \mathrm{mg} / \mathrm{L} / \mathrm{h}$. Although the rate of increase was rapid at the initial stage $(0.221 \mathrm{mg} / \mathrm{L} / \mathrm{h}$ at 24 hours) of sand+clay mixture, it became more gradual at the maximum $(0.039 \mathrm{mg} / \mathrm{L} / \mathrm{h})$ and continued to show a gradual decrease at a rate of $0.009 \mathrm{mg} / \mathrm{L} / \mathrm{h}$.

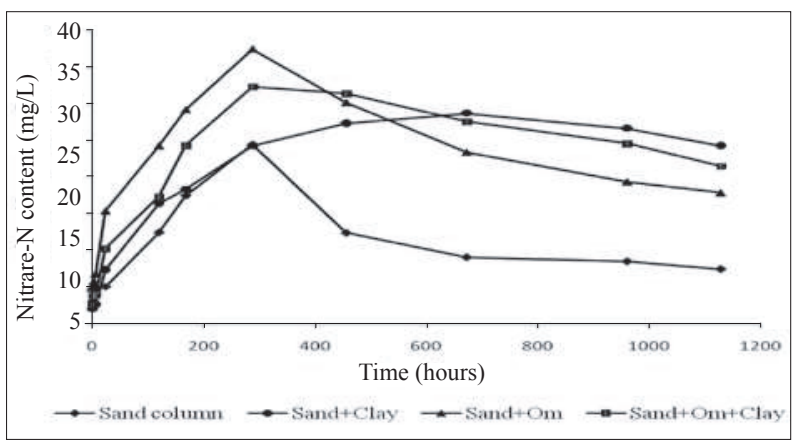

Figure 1: Variation of nitrate-N of the supernatant solutions of treated samples 
Therefore, the highest end-nitrate content $(24.72 \mathrm{mg} / \mathrm{L})$ was recorded from the sand+clay column. A similar trend was observed in the sand+clay+OM mixture, but the rate of rising $(0.318 \mathrm{mg} / \mathrm{L} / \mathrm{h}$ at 24 hour and $0.103 \mathrm{mg} / \mathrm{L} / \mathrm{h}$ at the maximum $)$, the rate of declining $(0.012 \mathrm{mg} / \mathrm{L} / \mathrm{h})$ and the end nitrate content $(21.55 \mathrm{mg} / \mathrm{L})$ were all lower than that of the sand+OM mixture. In contrast to the above variations, leached nitrate concentrations from the heated sand column treated with urea solution did not change with time.

\section{Nitrate rich groundwater as a fertilizer}

The mean height of the plants in bed A was higher than that of the plants in the field (Table 2). However, the best growth was seen in bed B, where both nitrate rich groundwater and other fertilizers (nitrate free) were added. The lowest growth was observed in plants of the field where water infiltration was allowed. It was clearly noted that there was a difference in the green colour between plants in the beds and in the field. The harvested yields of controlled and uncontrolled fields were markedly different (Table 2). The highest yield (weight) was shown by plants and bulbs from the bed B. Weight of $89 \%$ of the bulbs was higher than the mean weight of bulbs obtained from the field.

Table 2: Mean heights and weights of onion plants $(n=60)$

\begin{tabular}{lccc}
\hline Mean height (mm) & Bed A & Bed B & Field \\
\hline After 1 month & 12 & 13 & 10 \\
After 2 month & 34 & 40 & 32 \\
After 3 month & 35 & 41 & 34 \\
Mean wt of a plant (g) & 8.4 & 27.8 & 24.6 \\
Mean wt of a bulb (g) & - & 23.6 & 18.5 \\
\hline
\end{tabular}

\section{DISCUSSION}

\section{Nitrate retention in sands mixed with clay}

The sandy nature of the Kalpitiya soil with neutral $\mathrm{pH}$ and lack of fine fraction causes limited nitrate retention, hence rapid leaching and dry conditions cause more vulnerable situations in nutrient uptake (Harold et al., 2006; Hasson \& Wiley, 2010). Sufficient time for plant uptake can be allowed if nitrate is held within the root zone of the soil/unsaturated zone (Schröder et al., 2012). The present study showed that nitrate can be retained by mixing the Kalpitiya sandy soil with clay. The retention capacity increases with the increase of clay content. Generally clay particles, which are negatively charged due to replacement of cations tend to adsorb positively charged particles and/or cations (Kinjo \& Pratt, 1971; Wong et al., 1990; Gonzalezpradas et al., 1993; ReynoldsVargas et el., 1994). But Toner et al. (1989) showed that nitrate retention in clay, which is completely reversible is a simple electrostatic retention mechanism. Hence nitrate adsorption can be high when the soil is rich in cations. However, Rao (1998) has described that retention of nitrate in clayey soils is caused by the membrane effect of clay or due to its large ionic size. Thus, the nitrate in the solution is trapped with the clay particle network in soil and the trapping causes loosely bonded nitrate in the clay structure to increase with the increase of clay component of the soil. This is an important consideration in agricultural activities since the nitrate in soil solution needs to be retained to enable uptake by plants.

\section{Behaviour of urea in sandy soil}

The increase of nitrate in leachates of the columns indicated that urea has been converted into nitrate. Conversion of urea fertilizers into nitrate, known as nitrification (Lees \& Quastel, 1946; Walter et al., 1975), may be a microbial process (Francis et al., 2007). The differences in increase of nitrate signified the discrepancies in the conversion process in different soil media. Therefore, the rate of nitrification is inferred as a function of the soil type, which is characterized by the microbial density, the amount of soil oxygen and the particle size (Llinares et al., 1994; Burger \& Jackson, 2003; Norton \& Stark, 2011). Further, the amount of nitrate produced by nitrification depends on the concentration of urea applied to the soil. The applied urea hydrolyses rapidly in the soil into ammonia and carbon dioxide in the presence of urease enzyme (Warner, 1942; Laboski, 2006). The activity of urease enzyme increases with the increase in temperature. Hence, higher rate of breakdown of urea can be expected under dry climate and also ammonia can be volatilized due to dry, warm soil conditions (Sloan \& Anderson, 1995). Regular watering minimizes volatilization loss in agricultural lands. Therefore, it can be inferred that volatilization loss in the Kalpitiya sandy soil is likely to be low. The hydrated form of ammonia is converted into nitrite by the action of autotropic bacteria such as Nitrosomonas sp. (Heritage et al., 1999). However, ammonium ions can also be lost from the system if they are not converted into nitrite, and it can be the result of the low density of autotropic bacteria in the soil system. Nitrite is an unstable form and it is readily converted into nitrate by another group of autotropic bacteria such as Nitrobacter sp. (Heritage et al., 1999). Nitrate is readily soluble in the soil moisture, and has a greater mobility in 
the saturated zone of soil. Therefore, the nitrate content of the soil solution in columns increases over time and their rates are determined by the type of soil. The density of microbes depends on the soil type (Giller 1996; McCulley \& Burke, 2004; Lejon et al., 2007).

As shown in Figure 1, the variation of nitrate content is characterized with an initial increase (up to 600 hours) and a later decrease $(600-1128$ hours $)$ during the period of the experiment. More or less similar rates of increase were observed in sand, sand $+\mathrm{OM}$ and sand+clay+OM media columns with different nitrate contents in each column (Figure 1), which clearly indicates the effects of soil type on the nitrification process. It was observed that the sand+OM did not favour the nitrification process. This is possibly due to the presence of higher numbers of microorganisms in the media (Stark \& Firestone, 1995; Bottomley et al., 2004) or the decaying of organic manure may have released nitrate (Sommerfeldt et al., 1998; Niu et al., 2011) into the soil solution or both may have taken place in the sand+OM column. In contrast, sand+clay column shows a slower rate of increase. It can be inferred that the nitrate produced is retained by clay particles of the media as shown previously. In comparison, the two mechanisms by which the nitrate content is affected can take place in the sand+clay+OM column. During the increase of nitrate, it can be retained by the clay in the mixture and hence it reduces the concentration of nitrate in the soil solution. Meanwhile, the organic manure is able to increase the concentration of nitrate (Wang et al., 2008). Therefore, the amount of nitrate in the leachates from sand+clay $+\mathrm{OM}$ varies between that of sand $+\mathrm{OM}$ and sand+clay column.

The decrease of nitrate in columns resulted from the two mechanisms, limiting the production and reducing it with time. Nitrate production is limited by inhibition of the nitrification process, which depends on various factors such as urea content, oxygen content, temperature and the availability of microorganisms (Llinares et al., 1994; Burger \& Jackson, 2003; Norton \& Stark, 2011). However, the most significant factor would be the amount of oxygen as nitrification process consumes both urea and oxygen in the medium (White \& Reddy, 2002; Jechalke et al., 2011). Since the system contains excess amounts of urea and the other physical and chemical conditions prevailing have not been changed, it can be assumed that the main controlling factor is the availability of oxygen. Furthermore, the microorganisms consume some amount of oxygen for their biological respiration in addition to nitrification (Stenstrom \& Song, 1991; Jianlong \& Ning, 2003). Therefore the rate of the nitrification process decreases due to inadequate oxygen levels in the columns with time (Richardson, 2000). Also, nitrate is unstable under anaerobic conditions (Wlodarczyk et al., 2004) as anaerobic bacteria convert nitrate into nitrite and finally into nitrogen gas. The process is known as denitrification where heterotrophic and autotropic facultative bacterial communities like Paracoccus sp., Pseudomonas sp. and Thiobacillus sp. are involved (Zumft, 1997).

When the oxygen is completely consumed it was observed that the nitrate concentration in soil columns had reached their maximum. The recorded maximum concentrations were different in each column. Then, the concentration started to decrease (Figure 1) and the rates of decreasing varied with different soil media in columns (Table 2). It was clearly observed that the nitrate content has not changed over time in the column prepared from heated sand. Heating would have resulted in the inhibition of microbial activity (Peterson, 1962; Beck, 1983). Therefore, both increase (nitrification) and decrease (denitrification) of nitrates in soil column solutions over time may be a result of microbial processes.

The comparable variation of nitrate in the supernatant solution observed from both sand and sand+OM columns (Figure 1) indicated that both systems have similar conditions. The slow rate of decrease in sand+clay column (Figure 1) may have been caused by the slow release of nitrate retained in clay particles with the lowering of the concentration by the denitirification process. The release of nitrate into the soil solution may have taken place until the entire nitrate content retained in clay particles is depleted. However, it is possible to infer that the rate of release of nitrate is slower than that of the denitrification process or both had the similar rates (Toner et al., 1989). This exchange can be a slow process during which both nitrification and denitrification have been taking place simultaneously. Because of this, a sharp peak was not observed in the curve of the nitrate content of the sand+clay column. The amount of nitrate produced during the period of nitrification is high when organic manure and clay are added. It can be expected that the decay of organic matter may have enhanced the nitrification process by adding nitrate due to its decaying process (Kim et al., 1997; McLatchey \& Reddy, 1998).

Although both processes of nitrification and denitrification occur in soil columns, the situation in the Kalpitiya area is different. The Kalpitiya agricultural field is an active and dynamic environment because the area is extensively fertilized and intensively watered (Jayasingha et al., 2011). Despite the semi arid conditions of the area, the sandy soil of the agricultural areas retains soil moisture for a considerable period during daytime due to watering. Hence the applied urea fertilizer has sufficient contact time to dissolve in soil solution prior 
to percolation downward through highly permeable soil (Wild \& Cameron, 1980; Zaman et al., 2009). Fertilizer application is immediately followed by watering the fields. Shallow unconfined aquifer rich in nitrate or urea provides a significant input of nitrogen to crops through watering.

Intensive watering by sprinklers also aerates the water. Hence, soil solution is rich in oxygen resulting in aerobic conditions in sand favouring high nitrification rates. In addition, mixing of aerated water with groundwater in the saturated zone can facilitate nitrification of groundwater. Thus nitrification can occur both in the unsaturated zone and the saturated zone. Therefore, a particular zone of nitrification cannot be expected in the soil profile. However, building up of nitrate in groundwater appears to be a combined result of intensive watering and application of fertilizer. Thus agricultural activities in the area increase the risk of accumulation of nitrate in the groundwater.

\section{Productivity and use of nitrate enriched ground- water}

Three different rates of growth of onion plants were observed in this experiment (Table 3). The best growth in bed B (Figure 2B) indicated adequate and efficient uptake of the nutrients by the plants. Bed B, which was lined with polythene below the root zone was treated in the same manner as the field plot. Restricted infiltration allowed a longer time for uptake of nutrients. This resulted in a much better growth of the plants as well as a yield in bed $\mathrm{B}$ as compared to that of bed A. Bed A, which was supplied only with nitrate contaminated water, showed a normal growth of leaves but not the bulbs. Although plants in bed A had sufficient time to absorb nitrate and the leaves grew well, it was observed that the leaves were not strong to stand straight. This may be because there are other nutrients in fertilizers responsible for bulb growth and the strength of the leaves. The lowest plant growth was observed in the field but not in bed A or B. The field plants got both fertilizer and nitrate contaminated water. However, due to the infiltration, soils loose the nutrients within a short period, restricting nutrient uptake by the plants. It can be inferred that the lining below the root zone maximizes the contact time and hence enhances the nutrients in the soil. Retention of nitrate contaminated water in the lined beds minimizes the requirement for the application of nitrate fertilizers. This can cut down the cost incurred for nitrate fertilizer. In addition, restriction of infiltration of nitrate contaminated water and nutrient rich soil solution minimize the groundwater pollution in the aquifer. This approach in the agricultural areas can reduce the nitrate content in groundwater of the aquifer system and the groundwater will gradually get purified. Lining with natural impermeable layers like clay instead of polythene can act as a potential sink for nitrate and soluble fertilizers. It can also release the nutrients
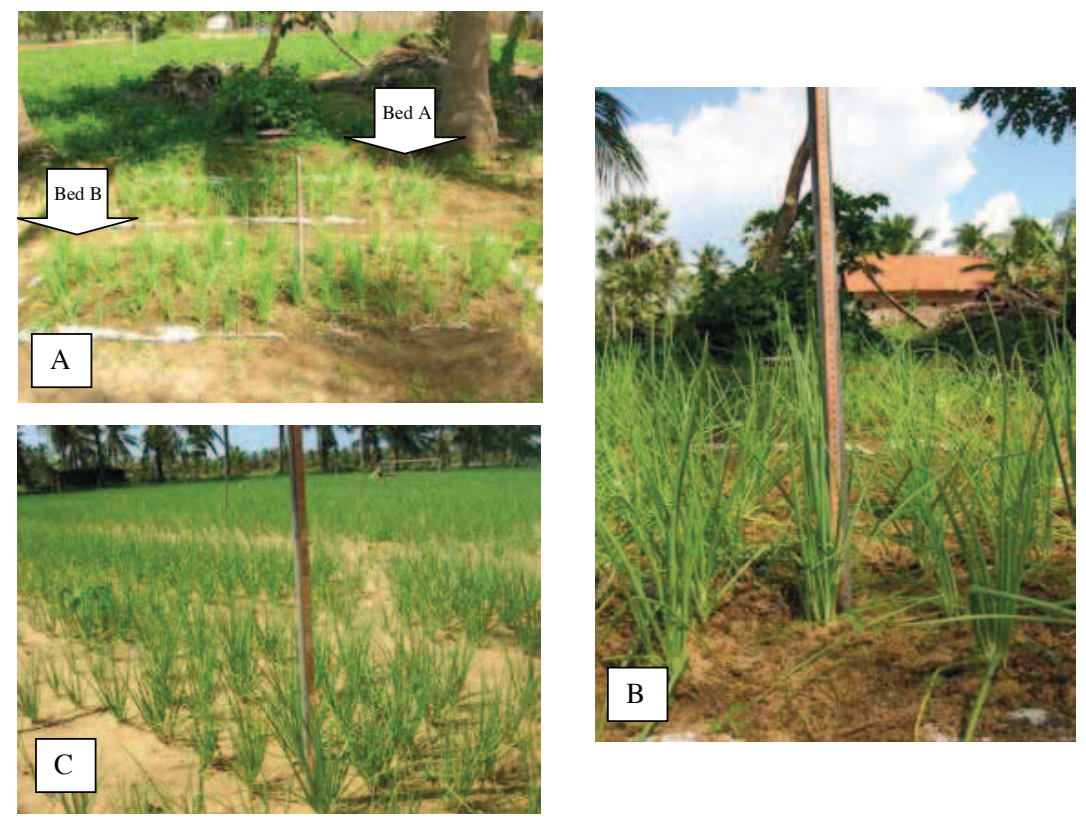

Figure 2: A; experimental plot of onion plants Bed A and Bed B, B; best growth shown by onion plants in Bed B, C; Onion plants in the field 
when their concentrations are low in soil solution (Rao, 1998).

\section{CONCLUSION}

The fate of the leached urea in soil columns is controlled mainly by the processes of nitrification and de-nitrification. Therefore, the rising and declining phases of nitrate content from soil columns are a result of the same processes. Thus, building up of nitrate in groundwater in the Kalpitiya agricultural fields could be attributed to continuous nitrification of leached urea. Laboratory experiments further revealed that clay and organic manure can be used to improve the quality of the Kalpitiya sandy soil and that clay acts as a potential sink to retain nitrate to be released afterwards. The organic manure can contribute as a nitrate source by decaying processes rather than acting as a medium to retain the leached nutrients. The special preparation of soil beds prevented direct infiltration of applied water in the field, hampering the leaching of dissolved nitrate into the aquifer. The final outcome would be the decrease of nitrate content in aquifer water and increased plant uptake. Reuse of already contaminated groundwater as a source of urea fertilizer can also decrease the need for applying nitrate fertilizers providing an extra cost benefit to the farmers.

\section{Acknowledgement}

The National Science Foundation of Sri Lanka is gratefully acknowledged for the financial assistance through grant no. NSF/RG/2007/AG/02. Authors wish to express their sincere thanks to Prof. Namal Priyantha, Senior Lecturer, Department of Chemistry, University of Peradeniya for his valuable comments and suggestions to enhance the quality of the paper.

\section{REFERENCES}

1. Ahmadil H., Akbarpour V., Dashti F. \& Shojaeian A. (2010). Effect of different levels of nitrogen fertilizers on yield; nitrate accumulation and several quantitative attributes of five Iranian spinach accessions. AmericanEurasian Journal of Agriculture \& Environmental Science 8(4): $468-473$.

2. ASTM Standard D422-63. (2007). Standard Test Method for Particle-Size Analysis of Soils. ASTM International, West Conshohocken, Pennsylvania, USA.

3. Beck T. (1983). Mineralization of soil nitrogen in laboratory incubation experiments. Z Pflanzenernähr Bodenk 120: $71-78$.

4. Bigelow C.A., Bowanan D.C. \& Cassel D.K. (2001).
Nitrogen leaching in sand based root zones amended with inorganic soil amendments and sphagnum peat. Journal of American Society of Horticulture Science 126(1): $151-156$.

5. Bottomley P.J., Taylor A.E., Boyle S.A., McMahon S.K., Rich J.J., Cromack Jr. K. \& Myrold D.D. (2004). Responses of nitrification and ammonia-oxidizing bacteria to reciprocal transfers of soil between adjacent coniferous forest and meadow vegetation in the Cascade Mountains of Oregon. Microbial Ecology 48: 500 - 508.

6. Burger M. \& Jackson L.E. (2003). Microbial immobilization of ammonium and nitrate in relation to ammonification and nitrification rates in organic and conventional cropping systems. Soil Biology and Biochemistry 35: 29 - 36.

7. Choudhury A.T.M.A. \& Kennedy I.R. (2005). Nitrogen fertilizer losses from rice soils and control of environmental pollution problems. Communications in Soil Science and Plant Analysis 35: 1625 - 1639.

8. Dean W.E. (1974). Determination of carbonate and organic matter in calcareous sediments and sedimentary rocks by loss on ignition: comparison with other methods. Journal of Sedimentary Petrology 44: $242-248$.

9. Evans C.D., Caporn S.J.M., Carroll J.A., Pilkington M.G., Wilson D.B., Ray N. \& Cresswell N. (2006). Modeling nitrogen saturation and carbon accumulation in heathland soils under elevated nitrogen deposition. Environmental Pollution 143: $468-478$.

10. Fan J., Hao M. \& Malhi S.S. (2010). Accumulation of nitrate- $\mathrm{N}$ in the soil profile and its implications for the environment under dry land agriculture in northern China: a review. Canadian Journal of Soil Science 90(3): $429-440$.

11. Francis C.A., Beman J.M. \& Kuypers M.M.M. (2007). New processes and players in the nitrogen cycle: the microbial ecology of anaerobic and archaeal ammonia oxidation. ISME Journal 1(1): 19 - 27.

12. Ghosh B.C. \& Bhat R. (1998). Environmental hazards of nitrogen loading in wetland rice fields. Environmental Pollution 102: 123 - 126.

13. Giller P.S. (1996). The diversity of soil communities, the 'poor man's tropical rain forest'. Biodiversity and Conservation 5: $135-168$.

14. Gonzalezpradas E., Villafrancassanchez M. \& Socciasviciana M. (1993). Phosphate and nitrate sorption on calcareous soils from Spain. Arid Soil Research Rehabilitation 7(2): $181-190$.

15. Guo H.Y., Zhu J.G., Wang X.R., Wu Z.H. \& Zhang Z. (2004). Case study on nitrogen and phosphorus emissions from paddy field in Taihu region. Environmental Geochemistry and Health 26(2): 209 - 219.

16. Gusman A.J. \& Marino A.M. (1999). Analytical modeling of nitrogen dynamics in soils and groundwater. Journal of Irrigation and Drainage Engineering 125(6): 330 - 337.

17. Hallberg G.R. (1989). Nitrate in groundwater in the United States. Nitrogen Management and Groundwater Protection (ed. R.F. Follee). Elsevier, Amsterdam, The Netherlands.

18. Harold M.E., Sogbedjib J.M. \& Schindelbecka R.R. (2006). Effect of manure application timing, crop, and soil type on 
nitrate leaching. Journal of Environmental Quality 35 (2): $670-679$.

19. Hasson A. \& Wiley T. (2010). Determination of the effect of $\mathrm{C} 4$ pastures to reduce nitrate-N leaching. Agriculture and Biology Journal of North America 1(1): 9-17.

20. Heritage J., Evan E.G.V. \& Kilinghton R.A. (1999). Microbiology in Action. Cambridge University Press, Cambridge, UK.

21. Jalali M. (2005). Nitrates leaching from agricultural land in Hamadan, western Iran. Agriculture, Ecosystems and Environment 110(3-4): $210-218$.

22. Jayasingha P., Pitawala A. \& Dharmagunawardhana H.A. (2011). Vulnerability of coastal aquifers due to nutrient pollution from agriculture: Kalpitiya, Sri Lanka. Water, Air, \& Soil Pollution 219(1-4): $563-577$.

23. Jechalke S., Rocell M., Vogt C. \& Richnow H.H. (2011). Inhibition of nitrification by low oxygen concentrations in an aerated treatment pond system with biofilm promoting mats. Water Environment Research 83(7): 622 - 626.

24. Jianlong W. \& Ning Y. (2003). Partial nitrification under limited dissolved oxygen conditions. Process Biochemistry 39: $1223-1229$.

25. Khalil M.I., Guster R. \& Schmidhalter U. (2009). Effects of urease and nitrification inhibitors added to urea on nitrous oxide emission from a loess soil. Journal of Plant Nutrition and Soil Science 172: $651-660$.

26. Kim D., Matsunda O. \& Yamamoto T. (1997). Nitrification, denitrification and nitrate reduction rates in the sediment of Hiroshima Bay, Japan. Journal of Oceanography 53: $317-324$.

27. Kinjo T. \& Pratt P.F. (1971). Nitrate adsorption; in some acid soils of Mexico and South America. Soil Science Society of America Proceedings 35: 722 - 725.

28. Kuruppurachchi D.S.P. \& Fernando W.A.R.N. (1999). Impact of agriculture on groundwater quality: leaching of fertilizers to groundwater in Kalpitiya Peninsula. Journal of Soil Science of Sri Lanka 11: 9 - 15.

29. Laboski C. (2006). Does it pay to use nitrification and urease inhibitors? Proceedings of the 2006 Wisconsin Fertilizer, Aglime and Pest Management Conference. 45: $45-50$.

30. Latifah O., Ahmed O.H. \& Muhamad A.M.N. (2011). Ammonia loss, ammonium and nitrate accumulation from mixing urea with zeolite and peat soil water under waterlogged condition. African Journal of Biotechnology 10(17): 3365 - 3369 .

31. Lawrence L.R. \& Kuruppuarachi D.S.P. (1986). Impact of agriculture on ground water quality in Kalpitiya, Sri Lankaimplications for future development. British Geological Survey Report WD/OS/86/20.

32. Lees H. \& Quastel J.H. (1946). Biochemistry of nitrification in soil; nitrification of varies organic nitrogen compounds. Biochemical Journal 40(5-6): 824 - 828.

33. Lejon D.P.H., Sebastia J., Lamy I., Chaussod R. \& Ranjard L. (2007). Relationships between soil organic status and microbial community density and genetic structure in two agricultural soils submitted to various types of organic management. Microbial Biology 53(4): 650 - 663.
34. Liang T., Wang H., Kung H.T. \& Zhang C.S. (2004). Agriculture land-use effects on nutrient losses in West Tiaoxi watershed, China. Journal of American Water Resource Association 40(6): 1499 - 1510.

35. Liyanage C.E., Thabrew M.I. \& Kuruppuarchchi D.S.P. (2000). Nitrate pollution in ground water of Kalpitiya; an evaluation of the content of nitrate in the water and food items cultivated in the area. Journal of the National Science Foundation of Sri Lanka 28(2): 101 - 112.

36. Liyang X.Q., Chen Y.X., Li H., Tian G.M., Ni W.Z., He M.M. \& Zhang Z.J. (2007). Modeling transport and fate of nitrogen from urea applied to a near-trench paddy field. Environmental Pollution 150: 313 - 320.

37. Llinares F., Munoz-Mingarro D., Pozuelo J.M. \& Ramos B. (1994). Microbial inhibition and nitrification potential in soil incubated with Elaeagnnnus angustifolia L. leaf litter. Geomicrobiology Journal 11: 149 - 156.

38. McCulley R.L. \& Burke I.C. (2004). Microbial community composition across the Great Plains: Landscape versus regional variability. Soil Science Society America Journal 68: $106-115$.

39. McLatchey G.P. \& Reddy K.R. (1998). Regulation of organic matter decomposition and nutrient release in a wetland soil. Journal of Environmental Quality 27(5): $1268-1274$.

40. Mubarak A.M., Gunawardhana H.P.G., Abeyratne D.J., Kuruppuarachchi D.S.P., Fernando W.A.R.N., Lawrence A.R., Stuart M.E. \& West J.M. (1992). Impact of agriculture on groundwater quality: Kalpitiya Peninsula, Sri Lanka. Hydrogeology Series, Technical Report WD/92/04. Final Report: British Geological Survey.

41. Nakasone H., Abbas M.A. \& Kuroda H. (2004). Nitrogen transport and transformation in packed soil columns from paddy fields. Paddy and Water Environment 2: 115 - 124.

42. Niu M., Zhang D., Wang S., Zhao M. \& Shi Y. (2011). Influence of the application rate of organic manure on nitrate migration and accumulation in greenhouse soil. International Conference on Computer Distributed Control and Intelligent Environmental Monitoring, pp. 864 - 867.

43. Norton J.M. \& Stark J.M. (2011). Regulation and measurement of nitrification in terrestrial systems. Methods in Enzymology (eds. M.G. Klotz), pp. 343 - 368. Academic Press, Burlington, Massachusetts, USA.

44. Peterson G.H. (1962). Microbial activity in heat and electron-sterilized soil seeded with microorganisms. Canadian Journal of Microbiology 8(4): 519 - 552.

45. Rao E.V.S.P. \& Puttana K. (1987). Nitrification and ammonia volatilization losses frodicyandiamide-treated urea in a sandy loam soil. Plant and Soil 97: 201-206.

46. Rao S.N. (1998). Impact of clayey soils on nitrate pollution in the groundwater of the lower Vamsadhara River basin, India. Hydrological Sciences Journal 43(5): 701-714.

47. Reynolds-Vargas J.S., Richter D.D. \& Bornemisza E. (1994). Environmental impacts of nitrification and nitrate adsorption in fertilized andisols in the Valle Central of Costa Rica. Soil Science 157(2): 289 - 299.

48. Richardson D.J. (2000). Bacterial respiration: a flexible process for a changing environment. Microbiology 146(3): $551-571$. 
49. Schlesinger W.H. (1997). Biogeochemistry: An Analysis of Global Change, $2^{\text {nd }}$ edition. Academic Press, San Diego, California, USA.

50. Schröder N., Javaux M., Vanderborght J., Steffen B. \& Vereecken H. (2012). Effect of root water and solute uptake on apparent soil dispersivity: a simulation study. Vadose Zone Journal 11(3) doi: 10.2136/vzj2012.0009.

51. Simpson J.R. (2006). The mechanism of surface nitrate accumulation on a bare fallow soil in Uganda. Journal of Soil Science 11(1): $45-60$.

52. Sloan J.J. \& Anderson W.B. (1995). Calcium chloride and ammonium thiosulphate as ammonia volatilization inhibitors for urea fertilizer. Communication of Soil Science and Plant Analysis 26(15-16): 2425 - 2447.

53. Sommerfeldt T.G., Chang C. \& Entz T. (1998). Long-term annual manure applications increase soil organic matter and nitrogen and decrease carbon to nitrogen ratio. Soil Science Society of America Journal 52(6): 1668 - 1672.

54. Stark J.M. \& Firestone M.K. (1995). Mechanisms for soil moisture effects on activity of nitrifying bacteria. Applied and Environmental Microbiology 61(1): 218 - 221.

55. Stenstrom M.K. \& Song S.S. (1991). Effects of oxygen transport limitation on nitrification in the activated sludge. Research Journal Water Pollution Control Federation 63: $208-219$.

56. Strebel O., Duynisveld W.H.M. \& Bottcher J. (1989). Nitrate pollution of ground water in Western Europe. Agriculture, Ecosystems and Environment 26(3-4): 189 - 214.

57. Toner C. V., Sparks D. L. \& Carski T. H. (1989). Anion exchange chemistry of middle Atlantic soils: charge properties and nitrate retention kinetics. Soil Science Society of America Journal 53(4): 1061 - 1067.

58. Walter M.F., Bubenzer G.D. \& Converse J.C. (1975). Predicting vertical movement of manorial nitrogen in soil. American Society of Agricultural and Biological Engineers 18: $100-105$.

59. Wang Y.P., Gao J.X., Liu S.H. \& Du X.G. (2008). Effect of organic manure on the profile distribution of soil nitrate-N in a peach orchard. Pub Med 19(7): $1501-1505$.

60. Warner R.C. (1942). The kinetics of the hydrolysis of urea and arginine. The Journal of Biological Chemistry 142: $705-723$.

61. White J.R. \& Reddy K.R. (2002). Nitrification and denitrification rates of Everglades wetland soils along a phosphorus - impacted gradient. Journal of Environmental Quality 32(6): 2436 - 2443.

62. Wild A. \& Cameron K.C. (1980). Soil nitrogen and nitrate leaching. Soils and Agriculture (ed. P.B. Tinker), pp. 35 - 70. Society of Chemistry Industry, Critical Reports on Applied Chemistry, Oxford Blackwell Scientific, Oxford, UK.

63. Wlodarczyk T., Stępniewski W., Brzezinska M. \& Stepniewska Z. (2004). Nitrate stability in loess soils under anaerobic conditions-laboratory studies. Journal of Plant Nutrition and Soil Science 167(6): 693 - 700.

64. Wong M.T.F., Rowell D.L. \& Hughes R. (1990). The retention of nitrate in acid soils from the tropics. Soil Use and Management 6(2): $72-74$.

65. Yoshinaga I., Feng Y.W., Singh R.K. \& Shiratani E. (2004). Dissolved nitrogen model for paddy field ponded water during irrigation period. Paddy and Water Environment 2: $145-152$.

66. Young S., Pitwala A. \& Gunathilaka J. (2010). Fate of phosphate and nitrate in waters of an intensive agricultural area in the dry zone of Sri Lanka. Paddy and Water Environment 8(1): 7 - 79 .

67. Zaman M., Saggar S., Blennerhassett J.D. \& Singh J. (2009). Effect of urease and nitrification inhibitors on $\mathrm{N}$ transformation, gaseous emissions of ammonia and nitrous oxide, pasture yield and $\mathrm{N}$ uptake in grazed pasture system. Soil Biology and Biochemistry 41(6): 1271 - 1280.

68. Zebarth B.J., Hii B., Liebcher H., Chipperfield K., Paul J.W., Grove G. \& Szeto S.Y. (1998). Agricultural land use practices and nitrate concentration in the Abbotsford aquifer, British Colombia, Canada. Journal of Agriculture Ecosystem and Environment 69(2): 99 - 112.

69. Zumft W.G. (1997). Cell biology and molecular basis of denitrification. Microbiology and Molecular Biology Review 61(5): $533-616$. 